\title{
Weather based pest forewarning models for mealybug infestation in Robusta coffee (Coffea canephora)
}

\author{
M. JAYAKUMAR ${ }^{1 *}$ and M. RAJAVEL ${ }^{2}$ \\ ${ }^{1}$ Regional Coffee Research Station, Thandigudi, Kodaikanal,Dindigul, Tamilnadu \\ ${ }^{2}$ Meteorological Centre, India Meteorological Department, Raipur, Chhattisgarh \\ Corresponding author's e-mail: jaykumararrcrs@gmail.com
}

\begin{abstract}
An investigation was carried out to study the effect of weather parameters on mealybug infestation in Robusta coffee and to develop forewarning model using 39 years (1977 to 2015) pest data on mealy bug damage in coffee plantations collected at Regional Coffee Research Station, Chundale, Wayanad district of Kerala were recorded at fortnightly intervals during 1977 to 2015 (39 years). The results revealed that mealybug infestation was found to vary with season and also year to year. Fruit setting and budding stages of coffee were severely damaged by mealy bug. Analysis indicated that annually, average damage due to mealy bug was 6.4 per cent and ranged between 5.4 per cent in 1984 to 9.7 per cent in 2011. The mealybug damage was maximum during summer season and lowest during South-West Monsoon (June-September) season. Season wise regression models were developed using data up to 2013 for forewarning per cent damage of mealy bug and validated for 2014 and 2015. The model for summer season mealybug damage has maximum $\mathrm{R}^{2}=0.79$ which can be used for operational forecasting of mealy bug damage.
\end{abstract}

Key words: Robusta coffee, Mealy bug, pest forewarning model, operational pest forecasting

Coffee, a beverage crop of commercial importance in India, cultivated mainly in hilly areas of Southern States in Karnataka, Tamil Nadu, Kerala and Andhra Pradesh (traditional areas). It is also grown in limited scale in some non-traditional areas of coffee in Orissa, West Bengal, Assam and Madhya Pradesh. Robusta coffee (Coffea canephora) is suited for cultivation in low altitude ranging from 500-1000 meters above mean sea level. It is cultivated in maximum area in Kerala than any other States in India. As majority of coffee area in Kerala comes under the elevation between 500-1000 meters above sea level, more than $85 \%$ of the coffee area is under Robusta coffee.

Mealybug, Planococcus citri is a highly polyphagous, feeds on many host plants in a variety of conditions with rapid reproduction capacity. It has been reported on over 200 hostplant species, and can seriously damage many crops, particularly citrus. Biotic and abiotic factors, as well as the host plants influence its population (Correa et al., 2008; Fand et al., 2018). Four Mealybug species namely Planococcus citri, P. lilacinus, P. minor and green scale, Coccus viridis, are important sucking pests of coffee in India. Distribution of coffee mealybug species in Wayanad district in Kerala was earlier reported by Rahiman and Prakash (2009). Among the Pseudococcids that attacks coffee in Wayanad, mealybug Planococcus citri (Risso) is one among the two major economically important species (Rahiman et al., 2010). P. citri is a pest on Arabica and Robusta coffee and young trees are occasionally killed by attack (Anonymous, 1988). They generally prefer warm, humid, sites away from harsh environmental conditions and natural enemies. Most mealybugs have a number of generations, often overlapping generations per year and their development is dependent on ambient temperature (Fand et al., 2014). Temperatures of about $25{ }^{\circ} \mathrm{C}$ and a high relative humidity are optimum for mealybugs and their populations reach peaks in spring and autumn (Hoffman, 2011). They are generally more problem in the dry season when water is lacking (Winston et al., 2005). Mealybugs can multiply rapidly especially in dry weather. Their numbers are reduced by prolonged or heavy rainfall (CABI, 2006). In Wayanad, mealybug ranks first in terms of severity of incidence compared to the borer pests like coffee berry borer and shot hole borer.

Heavy infestation of mealybugs ( $P$. citri) around the floral buds leads to deformity of the flowers and also sometimes cause total arrest of the blossom process (Kumar et al., 2016). The mealybugs can be usually damage the tender twigs, fruits and leaves. They suck the sap leading to debilitation of the plant and crop loss (Ramesh, 1987). The avoidable yield loss due to mealybugs in Robusta coffee is 14 
to 17 per cent. Crop loss can be enormous depending upon the level of infestation. Heavy infestation leads to development of fungus, Capnodium sp., on the honey dew secreted by the mealybugs which forms a black coating on the surface of the leaves. This can hinder the photosynthesis process as well as raise the surface temperature of the leaves. Sometimes the infestation is on the roots leading to serious damage to young seedlings in the field.

Correlation of weather parameters and pest population is an important pre-requisite for preparing pest forecasting model based on which pest incidence can be predicted, so that an effective pest management strategy can be planned in advance to prevent the pest reaching an action threshold level (Rao et al., 2006). In pest forewarning system, the variables of interest may be maximum pest population, pest population at most damaging stage of the crop, pest population at different stages of crop growth or at various standard weeks, time of first appearance of pests, time of maximum pest population, time of pest population crossing threshold limit, extent of damage, weekly monitoring of pest progress and occurrence / non-occurrence of pests (Kumar, 2014). Maruthathurai (2018) studied the effect of weather parameters on population dynamics of aphid on cashew in Goa. Rao et al. (2002) developed forecasting models for tea mosquito bug (Helopeltis antonii) of cashew in Karnataka. Jayakumar and Rajavel (2014) developed weather based forewarning models for coffee borer incidence in Wayanad district in Kerala.Therefore, an attempt has been made in this paper to investigate the statistical relationship between mealybug infestation and meteorological factors and also to develop forewarning models for predicting the damage percent of mealybug of coffee in Wayanad during successive seasons.

\section{MATERIALS AND METHODS}

The study was conducted at Regional Coffee Research Station (RCRS), Chundale, Wayanad district in Kerala. The objective of the work is to assess the seasonal incidence and influence of weather on mealy bug Planococcus citri (Risso) and to develop pest forewarning models. Weather data from January 1977 to December 2015 was used. Wayanad district is located in North Kerala which is in Western Ghats. Kerala has humid tropical climate. Research station is located in $11.605^{\circ}$ $\mathrm{N}$ latitude and $76.083^{\circ} \mathrm{E}$ longitude. It is situated at an elevation ranging from 700 to $2100 \mathrm{~m}$ above MSL.

According to India Meteorological Department, the four seasons are Winter (January to February), Summer (March and May), South West Monsoon or Monsoon (June to
September) and Post-monsoon or North East Monsoon (October to December). May is warmest month in the year with highest mean maximum temperature $\left(30.3{ }^{\circ} \mathrm{C}\right)$ and December is the coldest month of the year with lowest mean minimum temperature $\left(16.4^{\circ} \mathrm{C}\right)$. The average annual rainfall is $2500 \mathrm{~mm}$. The soil is acidic with medium Organic carbon content and low to medium phosphorus and potassium contents.

The study site covers an area of 116 hectares with 30 hectares of farm with adequate laboratory facilities for research. The coffee plantations grown in the station are Arabica and Robusta coffee with an average age of 40 to 50 years old. The experimental plots consist of one acre of Robusta coffee plantations (variety S-274). Pest data was recorded at fortnightly interval. Pest observations recorded from 20 selected coffee plants and in each plant, three branches at top, middle and bottom were chosen to record the population of mealy bug. The damaged flower buds/fruit branches were collected and per cent damage was worked out.

Table 1: Year-wise mean damage per cent and climate parameters

\begin{tabular}{rrrrrr}
\hline Year & Damage \% & Tmax & Tmin & RH & Rainfall \\
\hline 1991 & 6.0 & 29.1 & 18.4 & 88.6 & 2394.0 \\
1992 & 5.9 & 28.4 & 17.5 & 86.7 & 2895.2 \\
1993 & 6.1 & 29.3 & 19.1 & 83.5 & 3156.1 \\
1994 & 6.4 & 27.0 & 17.8 & 82.5 & 3679.2 \\
1995 & 6.0 & 27.8 & 17.9 & 71.6 & 2525.3 \\
1996 & 8.6 & 27.9 & 17.7 & 72.5 & 2795.7 \\
1997 & 8.2 & 27.4 & 18.1 & 84.1 & 3145.1 \\
1998 & 5.9 & 27.6 & 18.3 & 86.1 & 3010.2 \\
1999 & 7.3 & 27.8 & 18.5 & 86.8 & 2621.1 \\
2000 & 5.9 & 28.0 & 18.3 & 85.5 & 2670.9 \\
2001 & 7.1 & 27.7 & 19.0 & 84.8 & 2404.7 \\
2002 & 7.2 & 28.3 & 18.9 & 84.4 & 2366.8 \\
2003 & 7.4 & 28.6 & 19.0 & 85.3 & 2070.7 \\
2004 & 7.1 & 28.0 & 19.3 & 83.4 & 3054.7 \\
2005 & 8.0 & 27.1 & 19.4 & 85.2 & 3533.4 \\
2006 & 6.9 & 27.9 & 18.9 & 83.5 & 3785.0 \\
2007 & 6.4 & 28.5 & 19.2 & 84.7 & 3968.4 \\
2008 & 6.8 & 28.3 & 19.5 & 85.5 & 2770.9 \\
2009 & 8.8 & 29.3 & 19.1 & 83.5 & 3156.1 \\
2010 & 9.5 & 28.7 & 19.0 & 82.6 & 2798.4 \\
2011 & 10.3 & 28.3 & 18.8 & 80.1 & 3601.3 \\
2012 & 7.1 & 28.7 & 18.8 & 81.6 & 1957.0 \\
2013 & 6.3 & 29.6 & 20.3 & 88.9 & 3650.5 \\
\hline & & & & &
\end{tabular}




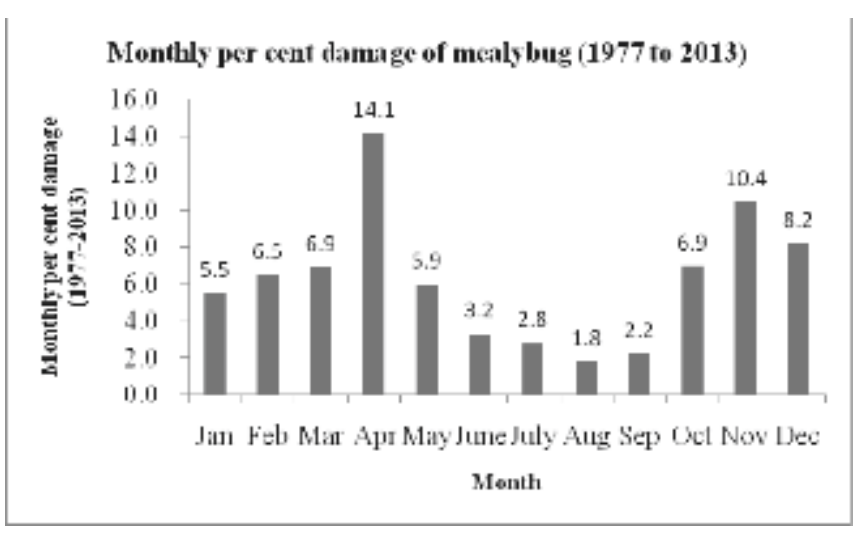

Fig.1: Monthly per cent damage of mealy bug

The data on weather parameters, maximum and minimum temperature $\left({ }^{\circ} \mathrm{C}\right)$, relative humidity (per cent) and rainfall $(\mathrm{mm})$ were recorded from Agrometeorological observatory installed in the station during the study period. The seasonal mean of pest damage of 20 plants were calculated from the data on the incidence of mealy bug and these were correlated with climatic parameters. Since the previous season's climatic parameters equally influence the damage level of the pest, climatic data of previous seasons to the reported infestation, was considered for correlation analysis. Correlation analysis between the seasonal pest damage and climatic factors in previous season were carried out for 1991 to 2013.

Simple correlation coefficient (CC) between pest damage and climatic parameters has been worked out for all four seasons. Student's ' $\mathrm{t}$ ' test was applied to test the significance of correlation coefficients. The season's individual climatic parameters having highest correlation coefficients $(\mathrm{P}<0.05)$ were identified. All these parameters were selected and multiple correlation and stepwise regression analysis was done by combining all the parameters and ' $F$ ' test was performed for testing its significance. In stepwise regression criteria of probability of $F$ test of a variable to enter is $\mathrm{F}<=0.05$, probability of $\mathrm{F}$ to remove is $\mathrm{F}>=0.10$. The statistical analysis was done using SPSS software, Version 16.0 developed by IBM, Bangalore, India. Regression equations were developed for each season using the significant climatic parameters having the highest correlation coefficients. Validation study has been done with observed pest damage during 2014 and 2015.

\section{RESULTS AND DISCUSSION}

\section{Seasonal incidence of mealy bug in Wayanad}

Annual average damage of mealybug (mean of 37 years) worked out to be 6.4 per cent. This annual mean damage per cent categorised as pest damage grade 1 as per the method of
Table 2: Correlation between mealy bug damage percent in different seasons and previous season climate

\begin{tabular}{|c|c|c|c|c|}
\hline $\begin{array}{l}\text { Previous } \\
\text { season }\end{array}$ & Tmax & Tmin & $\mathrm{RH}$ & $\mathrm{RF}$ \\
\hline \multicolumn{5}{|c|}{ Pest damage in winter season } \\
\hline Winter & -0.04 & 0.02 & -0.16 & 0.23 \\
\hline NW monsoon & 0.37 & 0.38 & -0.30 & -0.01 \\
\hline SW monsoon & 0.30 & 0.10 & -0.21 & -0.27 \\
\hline Summer & -0.31 & 0.20 & -0.30 & 0.21 \\
\hline \multicolumn{5}{|c|}{ Pest damage in summer season } \\
\hline Summer & -0.29 & 0.32 & -0.31 & 0.08 \\
\hline Winter & -0.18 & $0.48 *$ & -0.21 & 0.36 \\
\hline NE monsoon & -0.12 & 0.04 & -0.33 & 0.26 \\
\hline SW monsoon & $0.57 * *$ & 0.29 & -0.30 & 0.10 \\
\hline
\end{tabular}

Pest damage in south west monsoon season

$\begin{array}{lrrrr}\text { SW monsoon } & 0.05 & 0.00 & -0.25 & -0.18 \\ \text { Summer } & 0.01 & 0.01 & -0.52 * & 0.07 \\ \text { Winter } & -0.07 & 0.14 & -0.40 & 0.20 \\ \text { NE monsoon } & 0.16 & -0.04 & -0.52 * & 0.12\end{array}$

Pest damage in north east monsoon season

\begin{tabular}{lcccc} 
NE monsoon & -0.39 & -0.25 & -0.04 & $0.46^{*}$ \\
SW monsoon & $-0.51^{*}$ & $-0.44^{*}$ & 0.04 & -0.13 \\
Summer & -0.31 & -0.35 & 0.13 & 0.11 \\
Winter & -0.07 & -0.11 & -0.10 & 0.07 \\
\hline
\end{tabular}

Ces significant at 5\% level*, CCs significant at 1\% level**

Suresh et al. (2010) used for papaya mealy bug. There was increasing trend of pest damage in the span of 37 years with $\mathrm{R}^{2}$ value of 0.32 . Season wise distribution of mealy bug in coffee revealed that highest per cent damage was occur in summer season ( 9 per cent) followed by post-monsoon season ( 8.5 per cent) and winter ( 6 per cent). In Monsoon season, lowest per cent damage ( 2.5 per cent) of mealy bug was recorded. During summer, mealy bug damage was highest in April (14.1 per cent). During second highest damage season i.e. Postmonsoon season, damage was highest in November (10.4 per cent). Damage range from 5.5 to 6.5 per cent in winter and 1.8 to 3.2 per cent in Monsoon season. Heavy amount of rainfall associated with monsoon season may have washout effect on mealy bug population in coffee plantations.

There is no distinct variation in per cent damage between two fortnights and therefore month is considered as temporal scale for development of forewarning models. During maximum month of damage (April), first fortnight of April registered higher per cent damage (14.7 per cent) whereas 
Table 3: Regression equations for forewarning of mealy bug damage percent in different seasons

\begin{tabular}{llrrr}
\hline Season & \multicolumn{1}{c}{ Regression equation+ } & $\mathrm{R}^{2}$ & $\mathrm{~F}$ & Std. error \\
\hline Summer & $\mathrm{Y}=-3.959+(2.196 *$ Tmax SWM $)+(-1.043 *$ Tmax_NEM $)+(-0.117 *$ RH_NEM $)$ & 0.79 & 23.95 & 1.10 \\
SW monsoon & $\mathrm{Y}=9.093+(-0.073 *$ RH_NEM $)$ & 0.27 & 7.78 & 0.67 \\
NW monsoon & $\mathrm{Y}=27.361+(-0.857 *$ Tmax_SWM $)+(0.007 *$ Rain_NEM $)$ & 0.48 & 8.09 & 1.42 \\
\hline
\end{tabular}

+ include independent variable value for the season prior to prediction season in regression equation.

Table 4: Observed and predicted per cent damage of mealy bug

\begin{tabular}{lrrrrr}
\hline Season & \multicolumn{2}{c}{2014} & & \multicolumn{2}{c}{2015} \\
\cline { 2 - 3 } \cline { 5 - 6 } & $\begin{array}{r}\text { Predicted } \\
\text { damage }\end{array}$ & $\begin{array}{r}\text { Observed } \\
\text { damage }\end{array}$ & & $\begin{array}{r}\text { Predicted } \\
\text { damage }\end{array}$ & $\begin{array}{r}\text { Observed } \\
\text { damage }\end{array}$ \\
\hline Summer & 13.6 & 8.1 & & 13.7 & 6.4 \\
SW monsoon & 3.1 & 2.3 & & 2.5 & 7.5 \\
NE monsoon & 5.3 & 4.9 & & 4.3 & 7.2 \\
& & & & &
\end{tabular}

second fortnight of April recorded comparatively lesser per cent damage (13.6 per cent). Highest per cent damage (14.1 per cent) was recorded in April and second highest damage (10.4 per cent) was recorded in November (Fig. 1).

During maximum damage year 2011, pest damage range from 0-20 percent and during minimum damage year 1984, pest damage range from 1.5 to 13.2 percent. The peak damage in both the years was observed in April and least damage was recorded in July/August months. The secondary peak in damage observed during December (15 per cent) in maximum damage year and during November (12 per cent) in minimum damage year. This clearly reflects the variation in pest damage over years and months due to prevailing climate.

During maximum damage month of April, wide year to year variation was observed. Per cent damage range from 7.2 to 20.0 per cent. Maximum damage of mealy bug occurred during 2011 and minimum damage occurred in 1998. Similarly during minimum damage month of August, per cent damage range from 0 to 4 per cent. Maximum damage was observed during 2011 and no damage during 2007 to 2009. There was also negligible per cent damage during 2003 and 2004.

It has been observed that during mid-month of Summer (April) and Post-monsoon season (November), mealy bug damage was severe. During monsoon season, damage was high during initial months of the monsoon season (June and July) and low during August and September. The pattern of damage indicates that there are two distinct peak damage during April and November which correspond to fruit setting and budding stage of coffee.

\section{Correlation with climate parameters}

Year-wise mean percent damage from 1991 to 2013 along with corresponding climate data is provided in Table 1. Correlation coefficients worked out between seasonal per cent damage of mealy bug and different climate parameters from 1991-2013. Correlation studies indicated that different climate parameters influenced the pest damage differently (Table 2). In the present study, damage of mealy bug in winter season was found to have no significant correlations with previous seasons climate parameters. Maximum temperature in south west monsoon season had significant positive correlation (0.57) with mealy bug population in the summer season. Similar to maximum temperature, minimum temperature during winter season had significant positive correlation with pest damage during summer season. Rainfall and relative humidity in the previous seasons had no significant correlations with pest incidence levels in summer season. Relative humidity during summer and north east monsoon seasons has significant negative correlations $(-0.52)$ with pest damage in south west monsoon season. Temperature and rainfall had no significant correlations with pest damage in south west monsoon season. Maximum temperature during south west monsoon season had significant negative correlation (-0.51) with pest incidence of north east monsoon season. Similarly, minimum temperature during south west monsoon season had significant negative correlation $(-0.44)$ with pest damage of north east monsoon season. Rainfall during north east monsoon season had significant positive correlation (0.46) with pest occurrence of north east monsoon season. Relative humidity in previous seasons had no significant correlation with damage of subsequent north east monsoon season.

\section{Forewarning model}

The multiple regression equations for different seasons which quantify the pest damage with the help of significant climatic parameters influenced the pest damage were provided in Table 3. The multiple regression equation for forewarning 
the damage of mealy bug were validated for ascertaining accuracy of the models using climate parameters for 20142015.

Observed and predicted damage of mealybug is presented in Table 4. Developed models for different seasons could predict the mealybug in both the years with reasonable level of accuracy. Forewarning models could predict the percent damage with less error percent during north east monsoon season in 2014 and 2015. These model equations developed could be used for operational forecasting of mealy bug in different seasons of 2016. Climate data of year 2014 may be included for model equation development for forecasting of 2017 and in similar manner for subsequent years to account the influence of recent climate on mealy bug damage and to improve the accuracy of the forewarning models.

\section{CONCLUSIONS}

In a nutshell, there is increasing trend of annual damage in mealy bug in Kerala with possibility of increasing damage of mealy bug in the future due to climate change. Pest damage in different month revealed that the mealy bug activity is significantly high in dry months in summer and post-monsoon season due to favourable climate during these periods. Lower levels of mealy bug activity have been observed during wettest period of the year corresponding to monsoon season in India. There is positive correlation between mealy bug damage in summer season and temperature in previous months. In view of this, and also due to the findings of earlier studies pertaining to weather interactions with mealy bug, it may be concluded that temperature is dominant weather parameter influencing mealy bug damage in coffee plantations of Kerala. Further, the study has to be replicated in remaining coffee regions in India to find out whether temperature is dominant weather parameter controlling mealy bug incidence or any other parameter is influencing the mealy bug damage.

\section{REFERENCES}

Anonymous (1988). A compendium on pests and diseases of coffee and their management in India. Coffee Board Research Department, India, pp. 67.

CABI (2006). Pests and diseases of coffee in eastern Africa: a technical and advisory manual. (Eds. M. Rutherford and N. Phiri), CAB International, Wallingford, UK, pp.
70.

Correa, L.R.B., Santa-Cecilia, L.V.C., Souza, B. and Cividanes, F.J. (2008). Heat requirements of the white mealybug Planococcus citri, (Risso, 1813) (Hemiptera: Pseudococcidae) on coffee plants. Arquivos-do-Instituto-Biologico-Sao-Paulo, 75: 53-58.

Fand, B.B., Tonnang, H.E.Z., Bal, S.K. and Dhawan, A.K. (2018). Shift in the manifestations of insect pests under predicted climatic change scenarios: key challenges and adaptation strategies. In: "Advances in Crop Environment Interaction". (Eds. S.K. Bal et al.). pp. 389-404, Springer Nature Singapore Pte Ltd.

Fand, B.B., Tonnang, H.E.Z., Kumar, M., Bal, S.K., Singh, N.P., Rao, D.V.K.N., Kamble, A.L., Nangare, D.D. and Minhas, P.S. (2014). Predicting the impact of climate change on regional and seasonal abundance of the mealybug Phenacoccus solenopsis Tinsley (Hemiptera: Pseudococcidae) using temperature-driven phenology model linked to GIS. Ecol. Modelling, 288: 62-78.

Hoffman, H. (2011). Aphids, mealybugs and scales; common sap suckers in the home garden. Western Australian Agriculture Authority, Garden Note, 499: 1-4.

Jayakumar, M. and Rajavel, M. (2014). Weather based forewarning models for coffee borer incidence. $J$. Agrometeorol., 12(1):140-143.

Kumar, A. (2014). Weather based forewarning models for pest and diseases and yield loss Assessment, In: Forecasting Techniques in Agriculture". (Eds. K.N. Singh, A.

Kumar and H. Chandra, Indian Agricultural Statistics Research Institute (ICAR), New Delhi, pp.180-186.

Kumar, P.K.V., Reddy, G.V.M., Seetharama, H.G. and Balakrishnan, M.M. (2016). Coffee, In: Mealybugs and their management in Agricultural and Horticultural crops (Eds. M. Mani and C. Shivaraju), Springer India, New Delhi, pp.643-655.

Maruthadurai, R. (2018). Effect of weather parameters on population dynamics of aphid, Aphis odinae (van der Goot) (Hemiptera: Aphididae) on cashew in Goa. $J$. Agrometeorol., 20(1): 84-86.

Rahiman, A.P. and Prakash, R.N. (2009). Distribution of coffee mealybug species in Wayanad district in Kerala, 
J. Coffee Res., 37: 82-86.

Rahiman, A.P., Naik, P.R. and Vijayalakshmi, C.K. (2010). Field evaluation of coffee mealy bug parasitoid, Leptomastix dactylopii (How.) in Wayanad district of Kerala, India. Gregor Mendel Foundation J., 1: 62-67.

Ramesh, P.K. (1987). Observations on crop loss in robusta coffee due to mealy bug and shot- hole borer. Proceedings of workshop on the insect pest management strategies in coffee, Central Coffee Research Institute, Karnataka, India, Supplementary Coffee Res., 17: 94-95.
Rao, G.S.L.H.V.P., Raju, G.T.T., Puttaswamy, Krishnakumar, K.N., Tony, X. (2002). Forecasting tea mosquito bug (Helopeltis antonii) of cashew (Anacardium occidentale L.). J. Agrometeorol., 4(1): 45-52.

Rao, C.N., Shivankar, V.J. and Singh, S. (2006). Citrus Mealy Bug (Planococcus citri Risso) Management - A Review. Agric. Rev., 27: 142-146.

Winston, E., Op de Laak, J., Marsh, T., Lempke, H. and Chapmane, K. (2005). Arabica coffee manual for LaoPDR. FAO Regional Office for Asia and the Pacific, Bangkok. 